\title{
Seasonal Water Evaluation of Main Lagoons in the City of Sete
} Lagoas-MG

\author{
Bueno, G. H; Melo, C. P. O. F.; Madeira, A. P. C.; de Souza, A. G.; Garcia, \\ E. M.; Taroco, H. A.; Melo, J. O. F *
}

Rev. Virtual Quim., 2018, 10 (4), 863-874. Data de publicação na Web: 10 de julho de 2018

http://rvq.sbq.org.br

\section{Avaliação Sazonal da Água das Principais Lagoas da Cidade de Sete Lagoas-MG}

Resumo: A cidade de Sete Lagoas está inserida em um sistema cárstico e tem a presença de lagoas, que, em alguns casos, estão interligadas ao regime de aquíferos livres. Este trabalho teve como objeto avaliar a qualidade da água das lagoas Boa Vista, Brejão, Catarina, Cercadinho, José Felix, Mucuri e Paulino, presentes na cidade, ao longo de doze meses, através de análises físicas e químicas. Foram determinados parâmetros de $\mathrm{pH}$, condutividade, turbidez, cloreto, cálcio, magnésio, sódio e potássio. Os resultados demonstraram que as lagoas Paulino e Mucuri apresentaram maior índice de sódio e condutividade e, como estão localizadas na área central de Sete Lagoas, podem ter sido influenciadas por ações antrópicas. Além destas, a lagoa Brejão apresentou elevados valores de potássio, que podem estar relacionados com a atividade agrícola desenvolvida em seu entorno. Neste sentido, o estudo da qualidade das águas é de fundamental importância para que o município possa desenvolver medidas especificas de melhoria da qualidade das águas de cada lagoa e avaliar melhor o saneamento básico da cidade.

Palavras-chave: Qualidade; Água; Lagoas.

\begin{abstract}
The city of Sete Lagoas is set in a karst system and has the presence of lagoons, which, in some cases, are interconnected to the regime of free aquifers. The objective of this work was to evaluate the water quality of the lagoons of Boa Vista, Brejão, Catarina, Cercadinho, José Felix, Mucuri and Paulino, situated in the city, over a period of 12 months, through physical and chemical analyzes. Conductivity, pH, turbidity, chloride, calcium, magnesium, sodium and potassium parameters were determined. The results showed that the Paulino and Mucuri lagoons presented higher sodium and conductivity index and, since they are located in the central area of Sete Lagoas, may have been influenced by anthropic actions. In addition to these, the Brejão lagoon presented high values of potassium, which may be related to the agricultural activity developed in its environment. In this sense, the study of the water quality is of fundamental importance so that the county can develop specific measures to improve the quality of the waters of each pond and improve evaluating the basic sanitation of the city.
\end{abstract}

Keywords: Quality; Water; Lagoons.

* Universidade Federal de São João del Rei, Departamento de Ciências Exatas e Biológicas, Campus Sete Lagoas, Rodovia MG 424 Km-47, CEP 35701-970, Sete Lagoas-MG, Brasil.

Monesiomelo@gmail.com

DOI: $\underline{10.21577 / 1984-6835.20180063}$ 


\title{
Seasonal Water Evaluation of Main Lagoons in the City of Sete Lagoas-MG
}

\author{
Gustavo Hernandes Bueno, Carla Patrícia de O. F. Melo, Ana Paula C. \\ Madeira, Amauri Geraldo de Souza, Eric M. Garcia, Hosane Aparecida \\ Taroco, Júlio Onésio F. Melo*
}

Universidade Federal de São João del Rei, Departamento de Ciências Exatas e Biológicas, Campus Sete Lagoas, Rodovia MG 424 Km-47, CEP 35701-970, Sete Lagoas-MG, Brasil.

* onesiomelo@gmail.com

Recebido em 15 de janeiro de 2018. Aceito para publicação em 9 de julho de 2018

1. Introduction

2. Objectives

3. Material and Methods

4. Results an Discussion

5. Conclusion

\section{Introduction}

Water is the most essential fluid for the survival of most living organisms (plants, animals and microorganisms), as it serves as a transport means of vital nutrients to organisms and as an environment for the inhabitants of the oceans, lagoons and rivers. Besides, it is the most abundant liquid of the planet, occupying near $70 \%$ of its surface. Brazil owns $13.7 \%$ of the total surface freshwater of the planet and, despite the large volume of water available, the Brazilian population is not fully served. ${ }^{1}$

The rapid degradation of water resources has led to changes in legislation by government agencies, due to the indiscriminate use and occupation of the river banks and lagoons, mainly in the urban area, which has been provoking ecological changes, causing serious modifications in the landscape, the availability of habitats and the trophic composition of the aquatic environment. The sustainable management of water resources is crucially needed to meet growing demand, supply of urban populations and demand in rural areas for the expansion of agricultural production, with quality water. ${ }^{2}$

The city of Sete Lagoas, located in the northwest limit of the metropolitan region of Belo Horizonte, is considered the gateway of the Cerrado Minas Gerais, in the northnorthwest direction. The city has a diversified industrial park, opening food and automobile industries, among others. According to the Brazilian Institute of Geography and Statistics ${ }^{3}$ (IBGE, in portuguese), in 2016, the city had an estimated population of 234,221 inhabitants, with an area of $536,644 \mathrm{~km}^{2}$. 
Geologically the municipality of Sete Lagoas is inserted within the macrostructure of the São Francisco Craton, a unit characterized by pre-Cambrian formation and consolidation. The San Francisco Craton is a base for a very weak and shallow water basin where essentially marine pelitocarbon sediments were deposited on the stable epicontinental platform. ${ }^{4}$ It is located in the domains of the São Francisco river basin, but there are no watercourses with high flow in its territory. The Santa Helena's ridge plays the role of watershed divisor: the Paraopeba River and the Velhas' River. ${ }^{4}$

The karst system provides the presence of lagoons, which in some cases are interconnected to the regime of aquifers free of pelito-carbonate environments, such as Grande, Porcos, Remedios, Capivara and Feia lagoons. In the case of Paulino, Catarina, Boa Vista, Cercadinho, Vapabuçu, Catarina, Brejão and José Félix lagoons, located close to urbanized areas, do not show any association to the aquifers. ${ }^{4}$ Paulino and Mucuri are the two most central lagoons in the city, and have already undergone a process of degradation of their structure primary.

With the demographic growth of the city, there was an expansion of the urban area, mainly in the Brejão lagoon region, where the Federal University of São João del Rey was implanted. The expansions of urbanization in the region in the Brejão Lagoon played an obnoxious and important role on the lagoon: erosion due to the destruction of native vegetation, leaching of agricultural land, indiscriminate use of fertilizers, agricultural correctives, agrochemicals and deposits of degradable and non-degradable urban waste. Those factors contributed to the alteration of the chemical composition of water such as $\mathrm{pH}$ and salinity, as observed by Moraes et al., $2016,{ }^{5}$ regarding to the high levels of potassium found in the present lagoon.

Knowledge about water quality is necessary for a decision about the possibilities of its application for a specific purpose, avoiding the improper use of inferior quality water, and waste using potable water for less demanding uses.

The evaluation of physical-chemical parameters will inform the level of eutrophication of the lagoon, among others. Thus, these data are of great importance for the sustainable planning for the use of water by the municipality of Sete Lagoas.

\section{Objectives}

Evaluate the water quality in the chemical and physical-chemical aspects of the lagoons Boa Vista, Brejão, Catarina, Cercadinho, José Felix, Paulino and Mucuri, located in the urbanized region of Sete Lagoas, over 12 months, through analysis of chloride, calcium, magnesium, potassium, sodium, conductivity, turbidity and $\mathrm{pH}$.

\section{Material and Methods}

The study was lead in the Boa Vista, Brejão, Catarina, Cercadinho, José Felix, Paulino and Mucuri lagoons, located in the city of Sete Lagoas - MG.

The samples were collected from May 2015 to April 2016, in georeferenced points (Figure 1) and conditioned in polyethylene bottles, following the techniques of surface water collection, provided by the manual of sampling procedures and physical-chemical Water analysis. ${ }^{6}$ Each sample was collected by pond. After the collection, the samples were sent to the chemical laboratory of the UFSJCSL, where the following physic-chemical parameters were determined: chloride, calcium, magnesium, potassium, sodium, conductivity, turbidity and $\mathrm{pH}$. 


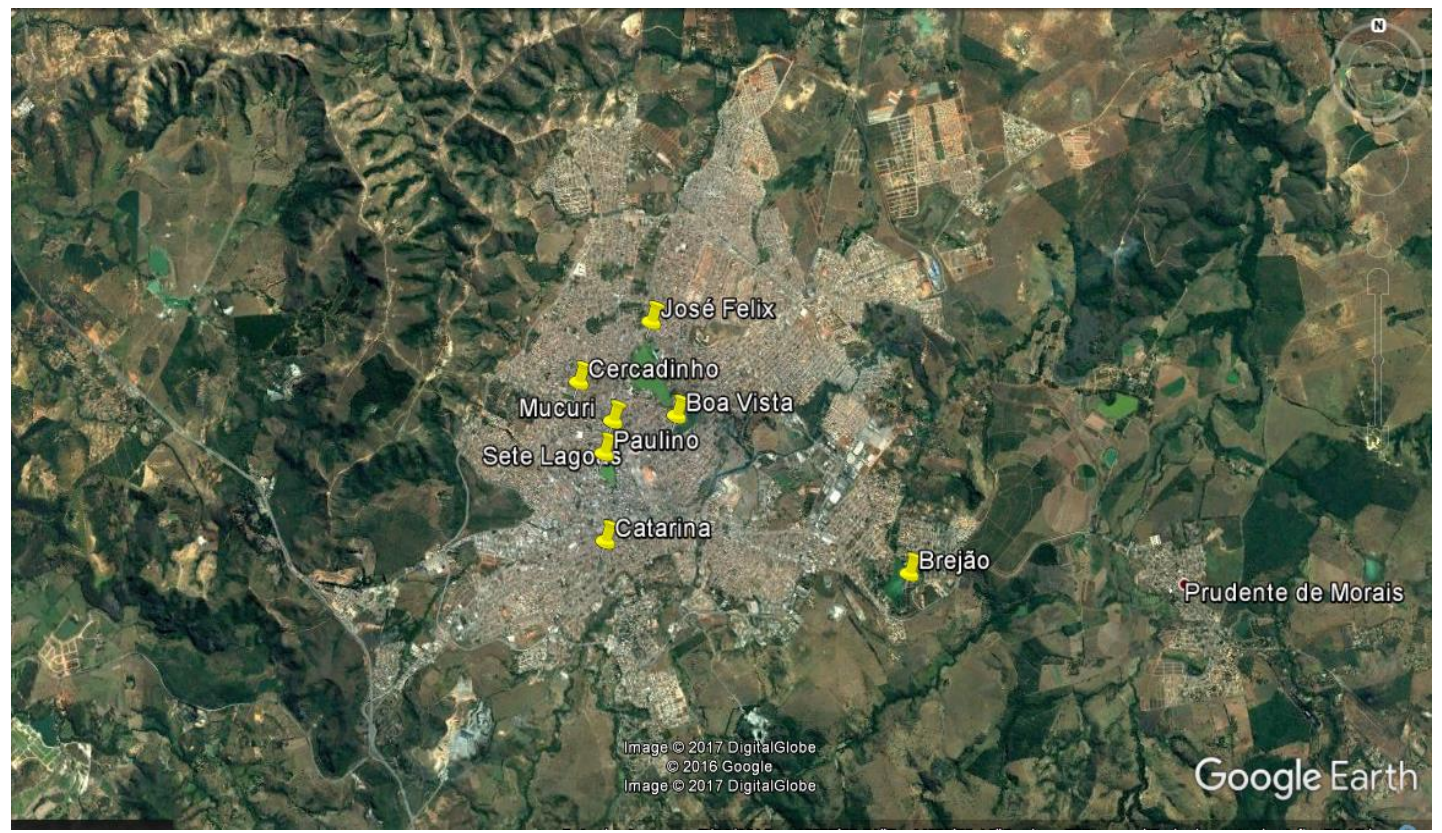

Figure 1. Geographical references of collection points of water samples. Source: Google $(2017)^{7}$

The potentiometric method was applied to determine the physicochemical parameters related to $\mathrm{Cl}$. For $\mathrm{pH}$, the bench $\mathrm{pH}$ meter of the Hanna Instruments brand was handled. Turbidity analyzes were performed using the Policontrol Ap2000 W turbidimeter. For conductivity analysis, the Hanna Instruments bench conductivity meter was manipulated. Calcium and magnesium content were determined by the complexation titration technique (titration with EDTA). For the potassium and sodium analyzes, the Flame Photometer (QUIMIS: Q498M2) was used.

\section{Results and Discussion}

The samples from the lagoons were subjected to $\mathrm{pH}$ determination, which term represents the concentration of hydrogen ions in a solution. In water, this factor is of exceptional importance, mainly in the treatment processes. The $\mathrm{pH}$ value varies from 0 to 14 . Below 7, the water is considered acidic and above 7 , alkaline, $\mathrm{pH} 7$ is considered neutral. ${ }^{8}$ Resolution 357/2005 of CONAMA $^{9}$ recommends that the $\mathrm{pH}$ of the water in the lagoons may be maintained in the range of 6.0 to 9.5. According to Table 1 , the $\mathrm{pH}$ results indicated values between 7.13 and 9.95, showing that most of the samples were within the range established by CONAMA. The results also indicated that the water contained in these lagoons under study is alkaline. The Boa Vista lagoon presented the highest average of $\mathrm{pH}$ compared to the others.

Compared with the results found by Moraes et al. in 2016, ${ }^{5}$ the $\mathrm{pH}$ values found for the Brejão Lagoon were higher. The variation of the $\mathrm{pH}$ values may be related to the concentration of $\mathrm{CO}_{3}{ }^{2-}$, through the effect of soil leaching, where alkaline substances come into contact with the water of the lagoons during months of high precipitation, as in the case of January. 
Bueno, G. H. et al.

Table 1. $\mathrm{pH}$ values for the ponds over the study period

\begin{tabular}{ccccccccc}
\hline pH & Catarina & Paulino & Mucuri & Cercadinho & $\begin{array}{c}\text { José } \\
\text { Felix }\end{array}$ & $\begin{array}{c}\text { Boa } \\
\text { Vista }\end{array}$ & Brejão & Average \\
\hline May & 7.45 & 7.9 & 7.85 & 8.25 & 8.04 & 8.08 & 8.04 & $\mathbf{7 . 9}$ \\
June & 8.79 & 8.75 & 8.11 & 7.5 & 7.73 & 8.84 & 8.2 & $\mathbf{8 . 3}$ \\
July & 9.22 & 9.08 & 7.84 & 8.78 & 9 & 9.28 & 8.68 & $\mathbf{8 . 8}$ \\
August & 8.12 & 8.8 & 8.2 & 8.63 & 9.15 & 9.11 & 8.64 & $\mathbf{8 . 7}$ \\
September & 8.95 & 9.46 & 8.12 & 9.46 & 9.61 & 9.33 & 8.92 & $\mathbf{9 . 1}$ \\
October & 9 & 8.34 & 7.93 & 9.4 & 7.55 & 9.92 & 8.53 & $\mathbf{8 . 7}$ \\
November & 7.86 & 7.13 & 7.67 & 8.17 & 7.39 & 7.38 & 7.42 & $\mathbf{7 . 6}$ \\
December & 7.37 & 7.41 & 7.49 & 7.51 & 7.25 & 7.61 & 7.39 & $\mathbf{7 . 4}$ \\
January & 9.23 & 9.15 & 8.48 & 9.95 & 9.4 & 9.08 & 8.81 & $\mathbf{9 . 2}$ \\
February & 8.3 & 8.76 & 7.47 & 8.12 & 7.57 & 8.06 & 8.32 & $\mathbf{8 . 1}$ \\
March & 7.8 & 7.42 & 7.49 & 7.7 & 7.59 & 8 & 7.52 & $\mathbf{7 . 6}$ \\
April & 8.74 & 9.08 & 8.01 & 8.75 & 9 & 9.62 & 8.53 & $\mathbf{8 . 8}$ \\
Average & $\mathbf{8 . 4}$ & $\mathbf{8 . 4}$ & $\mathbf{7 . 9}$ & $\mathbf{8 . 5}$ & $\mathbf{8 . 3}$ & $\mathbf{8 . 7}$ & $\mathbf{8 . 3}$ & \\
\hline
\end{tabular}

The electrical conductivity was verified as a function of the ionic concentration, mainly by the content of nutrients such as calcium, sodium, potassium, magnesium, carbonate, chlorides, among others. As for the concentration of dissolved solids in the water, the greater the electrical conductivity, being able to indicate corrosive characteristics in the water. ${ }^{10}$ According to Table 2 , the gaps have a conductivity ranging from 46.3 to $291.6 \mu \mathrm{S} /$ $\mathrm{cm}$.

A study by Lemos et al. in $2010^{2}$ was quoted as possible causes for increased conductivity: the high evaporation of water in the region and the anthropic activities developed along the margins of some of these lagoons.

It was perceived in this study that the conductivity increases progressively during the months with lower rainfall indexes, reaching the maximum in October. In 2014 and 2015 occurred the revitalization of Boa
Vista and Catarina lagoons, respectively, what explains by the fact they have lower values of conductivity, since they do not have accumulation of sediments. Did not happen to the Mucuri Lagoon, because it is located in the central region of the city, suffering more pollution due to urban activities, showing the highest numbers.

Natural waters contain sodium due to their abundance and high solubility of their salts, found in the ionic form $\left(\mathrm{Na}^{+}\right)$. In this sense, several concentrations of sodium in water bodies vary considerably, depending on local geological conditions and effluent discharges. ${ }^{6}$ The concentration of sodium in drinking water generally does not exceed $20 \mathrm{mg} / \mathrm{L}$ and the maximum recommended value of sodium in the water for drinking water is $200 \mathrm{mg} / \mathrm{L}^{9}{ }^{9}$ Most of the surface waters, including those that receive effluents, have sodium levels very lower than $50 \mathrm{mg} / \mathrm{L}^{10}$ 
Table 2. Conductivity values for lagoons over 12 months

\begin{tabular}{ccccccccc}
\hline Conductivity & Catarina & Paulino & Mucuri & Cercadinho & $\begin{array}{c}\text { José } \\
\text { Felix }\end{array}$ & $\begin{array}{c}\text { Boa } \\
\text { Vista }\end{array}$ & Brejão & Average \\
\hline May & 46.3 & 144.5 & 182.6 & 138.4 & 160.4 & 125.2 & 222 & $\mathbf{1 4 5 . 6}$ \\
June & 51.8 & 93.8 & 248.7 & 171.1 & 145.3 & 101.8 & 132.4 & $\mathbf{1 3 5 . 0}$ \\
July & 82.2 & 156 & 255.5 & 164.4 & 149.8 & 91.7 & 239.4 & $\mathbf{1 6 2 . 7}$ \\
August & 91 & 171.2 & 248.7 & 175.3 & 161.6 & 96 & 248.9 & $\mathbf{1 7 0 . 4}$ \\
September & 108.7 & 172.6 & 283.4 & 148.6 & 173.2 & 109.2 & 254.1 & $\mathbf{1 7 8 . 5}$ \\
October & 140.5 & 217 & 291.6 & 127.4 & 188.6 & 118.7 & 236.7 & $\mathbf{1 8 8 . 6}$ \\
November & 123.5 & 161.5 & 251.8 & 150.3 & 149.4 & 145.9 & 206.8 & $\mathbf{1 6 9 . 9}$ \\
December & 122.2 & 154.1 & 173.9 & 126.2 & 153 & 127.7 & 234.8 & $\mathbf{1 5 6 . 0}$ \\
January & 128.1 & 135 & 221 & 120.2 & 148.7 & 98.3 & 233.7 & $\mathbf{1 5 5 . 0}$ \\
February & 130.1 & 125.3 & 220.6 & 166.7 & 132.4 & 93 & 217.3 & $\mathbf{1 5 5 . 1}$ \\
March & 138.4 & 129.4 & 223 & 88 & 146 & 91.1 & 208 & $\mathbf{1 4 6 . 3}$ \\
April & 111.9 & 140.6 & 225.7 & 178.3 & 138.5 & 54.4 & 226.6 & $\mathbf{1 5 3 . 7}$ \\
Average & $\mathbf{1 0 6 . 2}$ & $\mathbf{1 5 0 . 1}$ & $\mathbf{2 3 5 . 5}$ & $\mathbf{1 4 6 . 2}$ & $\mathbf{1 5 3 . 9}$ & $\mathbf{1 0 4 . 4}$ & $\mathbf{2 2 1 . 7}$ & \\
\hline
\end{tabular}

According to the study in question in Table 3 , the month of September presented the highest average concentration of sodium in all the lagoons in a general way. Emphasizing that the lagoons Paulino, Mucuri and José Felix stand out in relation to the others, for having presented higher concentrations of sodium. This increase can also be attributed to the activities that occur in residences that border the lagoons as household waste, ${ }^{11}$ which can be leached or loaded to the lagoons.
The values found by Moraes et al..$^{5}$ for the Brejão Lagoon are lower than that found in this study. Compared with the results found by Marchesan et al. ${ }^{11}$ for the Vacaçaí and Vacaçaí-Mirim rivers, the values found in the lagoons were higher. In relation to water intended for human consumption, ${ }^{9}$ all lagoon averages were below the maximum limit. 
Bueno, G. H. et al.

Table 3. Sodium values for lagoons over 12 months

\begin{tabular}{ccccccccc}
\hline Sodium & Catarina & Paulino & Mucuri & Cercadinho & $\begin{array}{c}\text { José } \\
\text { Felix }\end{array}$ & $\begin{array}{c}\text { Boa } \\
\text { Vista }\end{array}$ & Brejão & Average \\
\hline May & 4.6 & 115 & 149 & 50.6 & 103.5 & 29.9 & 103.7 & $\mathbf{7 9 . 5}$ \\
June & 64.4 & 218.5 & 174.8 & 82.8 & 96.6 & 25.3 & 78.2 & $\mathbf{1 0 5 . 8}$ \\
July & 0 & 50.6 & 144.9 & 4.6 & 75.9 & 9.2 & 73.6 & $\mathbf{5 1 . 3}$ \\
August & 0 & 20.7 & 92 & 0 & 27.6 & 46 & 23 & $\mathbf{2 9 . 9}$ \\
September & 32.2 & 230 & 131.1 & 9.2 & 253 & 78.2 & 57.5 & $\mathbf{1 1 3 . 0}$ \\
October & 0 & 82.8 & 142.6 & 13.8 & 356.5 & 9.2 & 43.7 & $\mathbf{9 2 . 7}$ \\
November & 0 & 43.7 & 66.7 & 0 & 34.5 & 0 & 25.3 & $\mathbf{2 4 . 3}$ \\
December & 0 & 119.6 & 0 & 0 & 0 & 0 & 39.1 & $\mathbf{2 2 . 7}$ \\
January & 0 & 9.2 & 27.6 & 0 & 25.3 & 0 & 16.1 & $\mathbf{1 1 . 2}$ \\
February & 0 & 34.5 & 92 & 4.6 & 13.8 & 0 & 142.6 & $\mathbf{4 1 . 1}$ \\
March & 0 & 4.6 & 48.3 & 0 & 4.6 & 0 & 6.9 & $\mathbf{9 . 2}$ \\
April & 25.3 & 52.9 & 119.6 & 48.3 & 50.6 & 0 & 41.4 & $\mathbf{4 8 . 3}$ \\
Average & $\mathbf{1 0 . 5}$ & $\mathbf{8 1 . 8}$ & $\mathbf{9 9 . 1}$ & $\mathbf{1 7 . 8}$ & $\mathbf{8 6 . 8}$ & $\mathbf{1 6 . 5}$ & $\mathbf{5 4 . 3}$ & \\
\hline
\end{tabular}

According to Ferreira et al., ${ }^{10}$ potassium is an ion found in low concentrations in natural waters, as it comes from the rocks they contain are relatively resistant to weathering actions. Potassium salts are widely used in industry and fertilizers for Agriculture, and they enter the freshwater courses through industrial discharges and agricultural areas.
Table 4 shows that the mean concentration of potassium in the Brejão lagoon was higher than in the other lagoons. This fact may be related to the use of fertilizers at the margins of the lagoon. Moraes and collaborators in $2016^{5}$ found similar values to this study. Another fact to consider is that this lagoon is inserted in a region that performs agricultural activities. 
Table 4. Potassium values for lagoons over 12 months

\begin{tabular}{ccccccccc}
\hline Potassium & Catarina & Paulino & Mucuri & Cercadinho & $\begin{array}{c}\text { José } \\
\text { Felix }\end{array}$ & $\begin{array}{c}\text { Boa } \\
\text { Vista }\end{array}$ & Brejão & Average \\
\hline May & 5.6 & 11.2 & 5.7 & 11.3 & 11.3 & 11.5 & 28 & $\mathbf{1 2 . 1}$ \\
June & 15.6 & 15.6 & 7.8 & 11.7 & 7.8 & 7.8 & 23.4 & $\mathbf{1 2 . 8}$ \\
July & 0 & 3.9 & 3.9 & 0 & 3.9 & 3.9 & 11.7 & $\mathbf{3 . 9}$ \\
August & 0 & 0 & 0 & 0 & 0 & 3.9 & 7.8 & $\mathbf{1 . 7}$ \\
September & 3.9 & 7.8 & 3.9 & 0 & 11.7 & 3.9 & 11.7 & $\mathbf{6 . 1}$ \\
October & 3.9 & 3.9 & 3.9 & 0 & 3.9 & 3.9 & 7.8 & $\mathbf{3 . 9}$ \\
November & 3.9 & 0 & 0 & 0 & 3.9 & 3.9 & 3.9 & $\mathbf{2 . 2}$ \\
December & 0 & 7.8 & 3.9 & 0 & 0 & 0 & 11.7 & $\mathbf{3 . 3}$ \\
January & 0 & 0 & 0 & 0 & 3.9 & 0 & 11.7 & $\mathbf{2 . 2}$ \\
February & 3.9 & 3.9 & 3.9 & 3.9 & 3.9 & 3.9 & 23.4 & $\mathbf{6 . 7}$ \\
March & 0 & 0 & 3.9 & 0 & 3.9 & 0 & 7.8 & $\mathbf{2 . 2}$ \\
April & 3.9 & 0 & 0 & 0 & 3.9 & 0 & 11.7 & $\mathbf{2 . 8}$ \\
Average & $\mathbf{3 . 4}$ & $\mathbf{4 . 5}$ & $\mathbf{3 . 1}$ & $\mathbf{2 . 2}$ & $\mathbf{4 . 8}$ & $\mathbf{3 . 6}$ & $\mathbf{1 3 . 4}$ & \\
\hline
\end{tabular}

Just as potassium is important for agriculture and plants, the $\mathrm{Mg}^{2+}$ ion is an essential nutrient for life, has no harmful effect on health and aquatic life and its control is based on palatability, since present in large scale prints bitter taste to water. ${ }^{10}$ In minerals of magnesite $\left(\mathrm{MgCO}_{3}\right)$ and dolomite $\left(\mathrm{CaMg}\left(\mathrm{CO}_{3}\right)_{2}\right)$ it is found mainly in natural waters at concentrations close to $4 \mathrm{mg} / \mathrm{L}$ and in groundwater at concentrations of around 5 $\mathrm{mg} / \mathrm{L}^{6}$
As shown in Table 5 , magnesium values ranged from $1.68 \mathrm{mg} / \mathrm{L}$ to $73.92 \mathrm{mg} / \mathrm{L}$. It can also be observed that the seasonal variation of these lagoons is related to the rainy season, in months of January and February there was a considerable increase in magnesium concentration. Thus, it was observed that the magnesium values for natural waters are higher than those reported by Parron et al., ${ }^{6}$ when it was assumed that the lagoons surface has magnesite and dolomite minerals in its composition. 
Bueno, G. H. et al.

Table 5. Magnesium values for lagoons over 12 months

\begin{tabular}{ccccccccc}
\hline Magnesium & Catarina & Paulino & Mucuri & Cercadinho & $\begin{array}{c}\text { José } \\
\text { Felix }\end{array}$ & $\begin{array}{c}\text { Boa } \\
\text { Vista }\end{array}$ & Brejão & Average \\
\hline May & 12 & 6 & 8 & 4.7 & 1.7 & 9.1 & 7.8 & $\mathbf{7 . 0}$ \\
June & 9.24 & 9.24 & 29.4 & 9.24 & 21 & 7.56 & 26.04 & $\mathbf{1 6 . 0}$ \\
July & 6.72 & 6.72 & 10.08 & 3.36 & 3.36 & 3.36 & 8.4 & $\mathbf{6 . 0}$ \\
August & 6.72 & 6.72 & 8.4 & 5.04 & 5.04 & 18.48 & 31.92 & $\mathbf{1 1 . 8}$ \\
September & 11.76 & 6.72 & 3.36 & 3.36 & 3.36 & 6.72 & 3.36 & $\mathbf{5 . 5}$ \\
October & 11.76 & 5.04 & 1.68 & 3.36 & 5.04 & 10.08 & 8.4 & $\mathbf{6 . 5}$ \\
November & 8.4 & 1.68 & 3.36 & 31.92 & 3.36 & 1.68 & 18.48 & $\mathbf{9 . 8}$ \\
December & 30.24 & 8.4 & 16.8 & 16.8 & 63.84 & 6.72 & 28.56 & $\mathbf{2 4 . 5}$ \\
January & 40.32 & 25.2 & 23.52 & 25.2 & 50.4 & 18.48 & 18.48 & $\mathbf{2 8 . 8}$ \\
February & $\mathbf{7 3 . 9 2}$ & 52.08 & 38.64 & 25.2 & 42 & 23.52 & 35.28 & $\mathbf{4 1 . 5}$ \\
March & 35.28 & 21.84 & 15.12 & 11.76 & 18.48 & 20.16 & 13.44 & $\mathbf{1 9 . 4}$ \\
April & 13.44 & 6.72 & 8.4 & 5.04 & 5.04 & 16.8 & 6.72 & $\mathbf{8 . 9}$ \\
Average & $\mathbf{2 1 . 7}$ & $\mathbf{1 3 . 0}$ & $\mathbf{1 3 . 9}$ & $\mathbf{1 2 . 1}$ & $\mathbf{1 8 . 6}$ & $\mathbf{1 1 . 9}$ & $\mathbf{1 7 . 2}$ & \\
\hline
\end{tabular}

In the same sense, the following table shows the study carried out for the other very important parameter for fresh waters, which are chloride ions $\left(\mathrm{Ce}^{-}\right)$. They are usually present in raw and treated waters in concentrations ranging from small strokes up to hundreds of $\mathrm{mg} / \mathrm{L}$. It occurs in the form of sodium chlorides ( $\mathrm{NaCl}$ ), potassium chloride $(\mathrm{KCl})$ and magnesium chlorides $\left(\mathrm{MgCl}_{2}\right)$. The high concentrations of this ion can restrict the use of water due to the flavor they confer and the laxative effect they can cause. ${ }^{8}$
According to Table 6, it can be perceived that there was a seasonal variation between the lagoons, where all maintained a pattern of increase of the concentration of $\mathrm{Cl}^{-}$in the months between August and November, and then a decrease in the months of December until February. This increase can be related to the period of drought, registered between the months of September to November. Similarly, in another study conducted in 2016, by Moraes and collaborators ${ }^{5}$ found a variation of these ions, but with results higher than those found in this work. 
Table 6. Chloride values for lagoons over 12 months

\begin{tabular}{ccccccccc}
\hline Chloride & Catarina & Paulino & Mucuri & Cercadinho & $\begin{array}{c}\text { José } \\
\text { Felix }\end{array}$ & $\begin{array}{c}\text { Boa } \\
\text { Vista }\end{array}$ & Brejão & Average \\
\hline May & 56.8 & 100 & 104 & 77 & 141.5 & 73.7 & 124 & $\mathbf{9 6 . 7}$ \\
June & 27.95 & 18.61 & 16.66 & 8.57 & 11.95 & 4.74 & 17.29 & $\mathbf{1 5 . 1}$ \\
July & 3.53 & 12.86 & 22.39 & 7.67 & 13.35 & 3.66 & 18.61 & $\mathbf{1 1 . 7}$ \\
August & 109.63 & 25.96 & 27.95 & 11.95 & 20.8 & 6.38 & 24.11 & $\mathbf{3 2 . 4}$ \\
September & 17.94 & 23.23 & 33.61 & 10.31 & 14.37 & 7.39 & 87.83 & $\mathbf{2 7 . 8}$ \\
October & 52.37 & 38.97 & 48.64 & 141.98 & 43.53 & 158.62 & 65.36 & $\mathbf{7 8 . 5}$ \\
November & 45.17 & 27.95 & 52.37 & 17.29 & 20.8 & 11.1 & 31.22 & $\mathbf{2 9 . 4}$ \\
December & 8.57 & 9.23 & 17.29 & 7.96 & 13.35 & 7.67 & 25.96 & $\mathbf{1 2 . 9}$ \\
January & 7.67 & 19.31 & 17.29 & 8.26 & 12.4 & 2.94 & 20.8 & $\mathbf{1 2 . 7}$ \\
February & 2.35 & 6.87 & 10.7 & 4.74 & 6.87 & 2.63 & 14.37 & $\mathbf{6 . 9}$ \\
March & 8.26 & 9.23 & 12.4 & 4.92 & 6.62 & 3.53 & 11.95 & $\mathbf{8 . 1}$ \\
April & 31.22 & 16.66 & 22.39 & 7.67 & 12.86 & 6.15 & 23.23 & $\mathbf{1 7 . 2}$ \\
Average & $\mathbf{3 1 . 0}$ & $\mathbf{2 5 . 7}$ & $\mathbf{3 2 . 1}$ & $\mathbf{2 5 . 7}$ & $\mathbf{2 6 . 5}$ & $\mathbf{2 4 . 0}$ & $\mathbf{3 8 . 7}$ & \\
\hline
\end{tabular}

Another parameter to be considered by Brazilian legislation is the calcium ion $\left(\mathrm{Ca}^{2+}\right)$, commonly found in natural waters and originates from calcareous rocks and rocks containing iron-magnesium minerals and is the main responsible for the hardness of the waters. It is essential for animal life, and in high concentrations are relatively harmless to the organism. ${ }^{10}$ Ordinance No. 518/2004 of the Ministry of Health ${ }^{12}$ establishes for hardness the content of $500 \mathrm{mg} / \mathrm{L}$ in terms of $\mathrm{CaCO}_{3}$ as the maximum value allowed for drinking water.

According to Table 7, it was observed that calcium carbonate has a typical seasonal behavior, beginning in autumn with low values rising in the winter and reducing values in the spring and a small change occurring in the summer. This fact can be related to the process of soil leaching in periods of rain, where the calcium that is concentrated in soils and rocks is carried by the action of the rain up to the lagoons. Even with some alterations all the concentrations measured in the lagoons were within the value established by the Ministry of Health for drinking water. ${ }^{12}$

The turbidity of the water occurs due to the presence of solid materials in suspension, which reduce its transparency. It can also be caused by the presence of algae, plankton, organic matter and many other substances such as zinc, iron, manganese and sand, resulting from the natural process of erosion or domestic and industrial waste. In addition, turbidity serves as a sanitary indicator and pattern of acceptance of water for human consumption. ${ }^{8}$ Order No. 518/2004 of the Ministry of Health ${ }^{12}$ states that the maximum allowed value is 1.0 NTU for disinfected groundwater and filtered water after complete treatment or direct filtration. For water resulting from slow filtration the maximum allowed value is $2.0 \mathrm{NTU}$, and at any point in the distribution network 5.0 NTU as the acceptance standard for human consumption. 
Bueno, G. H. et al.

Table 7. Calcium values for lagoons over 12 months

\begin{tabular}{ccccccccc}
\hline Calcium & Catarina & Paulino & Mucuri & Cercadinho & $\begin{array}{c}\text { José } \\
\text { Felix }\end{array}$ & $\begin{array}{c}\text { Boa } \\
\text { Vista }\end{array}$ & Brejão & Average \\
\hline May & 46 & 54 & 92.2 & 87.6 & 66 & 53.2 & 88.8 & $\mathbf{6 9 . 7}$ \\
June & 53 & 53 & 60 & 55 & 19 & 36 & 75 & $\mathbf{5 0 . 1}$ \\
July & 44 & 58 & 98 & 76 & 60 & 46 & 102 & $\mathbf{6 9 . 1}$ \\
August & 46 & 122 & 110 & 86 & 68 & 42 & 108 & $\mathbf{8 3 . 1}$ \\
September & 60 & 54 & 96 & 60 & 54 & 36 & 94 & $\mathbf{6 4 . 9}$ \\
October & 42 & 56 & 98 & 58 & 58 & 36 & 84 & $\mathbf{6 1 . 7}$ \\
November & 50 & 36 & 64 & 48 & 44 & 40 & 62 & $\mathbf{4 9 . 1}$ \\
December & 30 & 52 & 56 & 32 & 40 & 50 & 66 & $\mathbf{4 6 . 6}$ \\
January & 60 & 42 & 60 & 38 & 32 & 34 & 74 & $\mathbf{4 8 . 6}$ \\
February & 64 & 48 & 86 & $\mathbf{7 2}$ & 56 & 48 & 80 & $\mathbf{6 4 . 9}$ \\
March & 66 & 50 & 84 & 74 & 62 & 42 & 82 & $\mathbf{6 5 . 7}$ \\
April & 46 & 48 & $\mathbf{7 8}$ & 76 & 54 & 16 & 84 & $\mathbf{5 7 . 4}$ \\
Average & $\mathbf{5 0 . 6}$ & $\mathbf{5 6 . 1}$ & $\mathbf{8 1 . 9}$ & $\mathbf{6 3 . 6}$ & $\mathbf{5 1 . 1}$ & $\mathbf{3 9 . 9}$ & $\mathbf{8 3 . 3}$ & \\
\hline
\end{tabular}

According to the analyzes, an increase in the turbidity parameter was observed in the winter, possibly with the reduction of the water volume of the lagoons, except for the Paulino Lagoon, which in the spring has an increase in the parameter. This being related to the release of a large amount of dirt and organic matter in the lagoon, owing to the large population found around it, which can be played directly or indirectly, due to the cleaning actions carried out by the population and not by the sewerage system.

Considering the study in question, it was very relevant, because it can evaluate directly or indirectly the main parameters required by the Brazilian Legislation in relation to fresh water. Besides all the methodologies used came against data from the literature.

\section{Conclusion}

According to the results obtained in this study, it is possible to affirm that there is a seasonal variation in the waters of the lagoons and that this variation occurs in a similar way between the lagoons, which may lead to some discrepancies of the evaluated parameters.

The central lagoons that were not revitalized (Paulino and Mucuri) may have undergone a major change in the parameters conductivity and sodium, due to the urban pressure with the release of domestic waste on them.

Catarina and Boa Vista lagoons, although located in the central area, have the best parameters due to the recent revitalization, but they cannot supply water for consumption, since their waters come basically from the rains, and the average depth of the lagoons is approximately $1 \mathrm{~m}$. In the dry period, they are practically empty.

The Cercadinho lagoon was not revitalized, but has physical and chemical parameters close to those of the Catarina and Boa Vista lagoons, since the urbanization process is recent, but most of it is also supplied by the rainwater.

The José Felix and Brejão lagoons have a considerable volume of water and do not 
suffer alterations in their volume, since the main source of feed are underground water mines, but they present some negative parameters, such as potassium.

Physical-chemical analyzes also showed that lagoons may present water with potential for human consumption because they have sodium concentrations and $\mathrm{pH}$ values within the parameters established by the Ministry of Health.

There is a need for future studies to compare if the seasonal variation found in this study is maintained, or if it changes over time, evidencing an improvement or worsening of its physical-chemical parameters. Although this study has been an academic one, it can be demonstrated and used by local managers to search for solutions to improve lagoon waters over time, effectively addressing each source of pollution. Each lagoon has specific characteristics and interventions are needed based mainly on the chemical and physicochemical analyzes, which give indications of contamination and poor conservation of them.

\section{References}

${ }^{1}$ Cardoso, D. C.; Dissertação de Graduação. Universidade Estadual de Feira de Santana, 2010. [Link]

${ }^{2}$ Lemos, M.; Neto, M. F.; Dias, N. Sazonalidade e variabilidade espacial da qualidade da água na Lagoa do Apodi, RN. Revista Brasileira de Engenharia Agrícola e Ambiental 2010, 14, 155. [CrossRef]

${ }^{3}$ IBGE. Instituto Brasileiro de Geografia e Estatística. 2017. Disponível em: <http://cod.ibge.gov.br/4ST>. Acesso em: 17 maio 2017.

${ }^{4}$ Botelho, L. A. L. A.; Dissertação de Mestrado, Universidade Federal de Minas Gerais, 2008. [Link]
${ }^{5}$ Moraes, F. A.; Ferreira, L. C.; Garcia, E. M.; Taroco, H. A.; Melo, J. O. F. Seasonal assessment of physical and chemical parameters of alternative sources of water from Sete Lagoas - MG. Scientific Electronic Archives 2016, 9, 17. [Link]

${ }^{6}$ Parron, L. M.; Muniz, D. H. F.; Pereira, C. M. Manual de procedimentos de amostragem e análise físico-química de água. Colombo: Embrapa Florestas, 2011. [Link]

${ }^{7}$ Google. Google Earth. Version 7.1.8.3036. 2017. Sete Lagoas. Disponível em: <https://www.google.com.br/earth/downloa d/ge/agree.html>. Acesso em: 17 maio 2017.

${ }^{8}$ Brasil. Fundação Nacional de Saúde. Manual prático de análise de água / Fundação Nacional de Saúde - 4. ed. - Brasília: Funasa, 2013, 150. [Link]

${ }^{9}$ Brasil. Ministério do Meio Ambiente. Conselho Nacional do Meio Ambiente. Resolução no 357, de 17 de março de 2005. Dispõe sobre a classificação dos corpos de água e diretrizes ambientais para o seu enquadramento, bem como estabelece as condições e padrões de lançamento de efluentes, e da outras providencias. Diário Oficial da União, Brasília, DF, 17 mar. 2005. Seção 1, 58. [Link]

${ }^{10}$ Ferreira, P. M. L.; Queiroz, M. M. F.; Sousa, T. M. I.; Garrido, J. W. A.; Costa, F. F. Qualidade físico-química da água para irrigação do Rio Piancó Piranhas Açu na cidade de Pombal-PB. Revista Verde de Agroecologia e Desenvolvimento Sustentável 2014, 9, 78. [Link]

${ }^{11}$ Marchesan, E.; Sartori, G. M. S.; Reimche, G. B.; Avila, L. A. D.; Zanella, R.; Machado, S. D. O.; Cogo, J. P. Qualidade de água dos rios Vacacaí e Vacacaí-Mirim no Estado do Rio Grande do Sul, Brasil. Ciência Rural 2009, 39, 2050. [CrossRef]

12 Brasil. Ministério da Saúde. Portaria no. 518, de 25.03.04. Dispõe sobre normas e padrões de potabilidade de água para consumo humano. Diário Oficial da União, Brasília, 26 de março 2004, Seção 1, 266. [Link] 